ЗАСТОСУВАННЯ СЕРЕДОВИЩНОГО ПІДХОДУ В ПРОЦЕСІ АНГЛОМОВНОї ПРОФЕСІЙНОЇ ПІДГОТОВКИ МАЙБУТНІХ ЛІКАРІВ

\title{
APPLICATION OF ENVIRONMENTAL APPROACH IN THE PROCESS OF ENGLISH-LANGUAGE PROFESSIONAL TRAINING OF FUTURE DOCTORS
}

Докорінні зміни, що відбулися в суспільному житті нашої країни, зробили необхідним володіння іноземною мовою як засобом міжкультурного спілкування. Тож сьогодні на рівні вищої медичної школи вивчення іноземної мови як засобу спілкування не тільки вирішує вузьке завдання підготовки майбутніх лікарів до англомовної профресійної діяльності, але й більш фрундаментальне - формування досвідченого лікаря. Добре відомо, що основними характеристиками викладання англійської мови в нелінгвістичних закладах вищої освіти є створення англомовного середовища. Медичні вищі навчальні заклади не $\epsilon$ винятком у цьому процесі. Метою статmі $\epsilon$ вивчення феноменів «середовище», «англомовне середовище» в контексті англомовноі просресійної підготовки майбутніх лікарів. Створення штучного англомовного середовища за відсутності природного мовного середовища дає можливість підвищити знання англійської мови студентів, створюючи ситуацію профеесійного спілкування за допомогою інтерактивних методів. Принцип передбачає не навчання студентів англійської мови як системи, а англомовне спілкування. За наявності англомовного середовища для виклику та пошуку можливостей залучення до навчального прочесу носіїв мови майбутні лікарі мають можливість застосовувати знання на практиці. Зміст вищезазначеної педагогічної умови передбачає організацію активної професійно зорієнтованоі навчально-мовленнєвої діяльності майбутніх лікарів на модельованих комунікативних і рольових квазіпрофесійних ситуаціях з метою заохочення студентів до англомовної професійної діяльності в межах роботи, спрямованої на набуття певних мовленнєвих навичок і застосування англомовної медичної лексики. Серед таких форм і засобів ми відзначимо: бізнес і рольові ігри, дебати, дискусії, вирішення конорліктів, участь у профрілактичних заходах; конференції звітності, мовну практику з носіями мови тощо. Процес професійної мовленнєвої діяльності майбутніх лікарів супроводжувався мовленнє вими та немовленнєвими ситуаціями, в яких вони думали і діяли у межах певної ролі, що сприяло набуттю англомовних профресійних навичок, збагаченню життєвого досвіду студентів, розвитку творчих і комунікативних здібностей та вмінню спілкуватися англійСькою мовою з їі носіями.

Ключові слова: англомовне мовленнєве середовище, професійна підготовка, майбутні лікарі.
The radical changes occurring in the social life of our country, made the necessary proficiency in the foreign language as means of intercultural communication. So today at the level of senior medical school learning a foreign language as a means of communication not only solves the narrow task of training future doctors language medical focus, but also more fundamental - the formation of an experienced doctor. It is well known that the main characteristics of English language teaching in non-linguistic universities is the creation of an English-speaking environment. Medical higher educational institutions is no exception in this process. The purpose of this article is to study the phenomena of "environment", "English speaking environment" in the context of English professional preparation of future doctors. The creation of an artificial English speaking environment in the absence of natural language environment gives you the opportunity to boost the English skills of students, creating a situation of professional communication using interactive methods. The principle is teaching students a foreign language not as a system, but foreign-language communication by means of the language. This principle provides for the presence of a language environment to call and seek opportunities to involve in educational process of native speakers, which allows future doctors to apply the knowledge in practice. The content of the above mentioned pedagogical condition provides for the organization of active professionally oriented educational and speech activities of future doctors on modeled communicative and role quasi-professional situations in order to encourage students to professional and speech medical activities within the framework of working with students acquired knowledge of language teaching material and specific skills and application of medical vocabulary. Among the following forms and means we will mark the following: business, role-playing games, debates, discussions, conflict resolutions, participation in preventive measures; reporting conferences, language practice with native speakers, etc. The process of professional speech activity of future doctors is accompanied by speech and non-speech circumstances in which they think and act within the profession in accordance with the situation and their roles in it, which as a result promotes the acquisition of practical skills in the profession, the enrichment of students' life experience, development of creative non-standard and communication skills and ability to communicate in English with native English speakers.

Key words: English-speaking environment, professional preparation, future doctors.
Виклад основного матеріалу. Розглянемо передусім поняття «середовище». У довідковому словнику В. Даля знаходимо: «середовище, речовина, тіло, пласт», «простір, площа» [5; с. 511]. Поняття «середовище» розкривається як «обстановка, сукупність природних умов, за яких протікає діяльність людського суспільства, організмів», «довколишні соціально-побутові умови, обста- новка, а також сукупність людей, пов'язаних спільністю цих умов» [2, с. 749].

$€$ низка визначень поняття «середовище», але, незважаючи на їх розмаїття, кожне 3 них має інваріантні ознаки. У сучасних дослідженнях «середовище» характеризується як оточення, сукупність природних умов; навколишні соціально-побутові умови; сукупність людей, пов'язаних спільністю 
життєвих умов; громадська група, до якої належить людина і яка складає коло її найближчого спілкування; соціальні, культурні економічні чинники та природні умови життя людей; сукупність умов, що оточують людину і взаємодіють 3 нею як з організмом і особистістю. У тлумачному словнику сучасної української мови подано тлумачення терміна «середовище» як сукупності природних умов, за яких відбувається життєдіяльність будьякого організму [4]. Словник С. Ожегова визначає «середовище» як заповнене просторовонаочне, природне і соціальне оточення людини, причому вказує, що несприятливе оточення не дає можливості особистості зростати та розвиватися [2, с. 812]. Отже, «середовище» $€$ зовнішнім простором, який оточує певний об'єкт, має системно організовані складники та створює умови для існування його у просторі та взаємодіє з ним.

Термін «мовне середовище» тлумачать по-різному. Наприклад, В. Ясвін розглядає мовне середовище як частину освітнього простору, як зону взаємодії освітніх систем, їх елементів, освітнього матеріалу і суб'єктів освітніх процесів [6, с. 215].

Створення штучного англомовного середовища за відсутності природного мовного середовища дає можливість стимулювати англомовні вміння студентів, створюючи ситуації професійного спілкування 3 використанням інтерактивних методів. Принцип полягає не в навчанні студентів іноземної мови як системи, а в іншомовному спілкуванні. Зазначений принцип передбачає присутність відповідного мовного середовища у ЗВО і пошук можливостей залучати до навчального процесу носіїв мови, що дозволяє майбутнім лікарям застосовувати отримані знання на практиці. Звернімо увагу на сучасні інноваційні освітні простори, де поняття «середовище» розглядається як основа освітнього процесу і виступає мобільним, цілеспрямованим, інтенсивним засобом для отримання освіти у будь-якому місці, за індивідуальним графріком, причому міжособистісна взаємодія відбувається електронними засобами навчання. На думку Н. Бурцевої, модель освітнього середовища університету, крім традиційних компонентів, повинна містити ще той, який характеризує відповідність середовища сучасному соціальному замовленню. 3 огляду на зазначене ця модель повинна мати такі структурні компоненти: 1) простір організації середовища, що проектується і фрормується відповідно до запитів і соціальних вимог; 2) носіїв інсрормації, 3) взаємодію суб'єктів і об'єктів, які входять до проектованого освітнього середовища, 4) освітні кластери $з$ іншими середовищами [1]. Означені компоненти освітнього середовища не можуть існувати автономно, вони взаємодоповнюються. На перше місце виходить якісна профресійна підготовка спеціаліста для ринку праці, що поєднує у своїй структурі культурний, освітній, профресійний, науковий, комунікативний, соціальний, комунікаційний компоненти, які сприяють розширенню можливостей майбутнього лікаря, дозволяють задовольнити його особисті запити та вимоги роботодавців, сприятимуть у майбутньому професійній мобільності, прагненню до самостійності у навчанні та саморозвитку.

Вивчивши наукові дослідження, пов'язані зі створенням розвивального середовища (Л. Виготський, П. Гальперін, Л. Занков, О. Леонтьєв), і взявши за основу тлумачення френомену «мовне середовище», визначимо поняття «розвивальне англомовне середовище», яке розумітимемо як сукупність чинників: просторово-предметного, технологічного і соціального, що забезпечують активізацію діяльності студентів на заняттях з англійської мови, створюють відповідну емоційну усталеність і сприяють оволодінню навичками англомовної комунікації.

Підсумовуючи погляди вчених, доходимо висновку, що зміст вищеозначеної педагогічної умови передбачає організацію активної профресійно зорієнтованої освітньо-мовленнєвої діяльності майбутніх лікарів за змодельованими комунікативними та рольовими квазіпрофесійними ситуаціями з метою спонукання студентів до професійно-мовленнєвої медичної діяльності в межах роботи з текстами та іншомовними мовцями, в ході яких студенти-медики демонструють отримані знання $з$ мовного навчального матеріалу та специфічні вміння і навички застосування медичної лексики. Серед таких фрорм і засобів відзначимо такі: ділові, рольові ігри, диспути, дискусії, розв'язання конорліктних ситуацій, участь у профрілактичних заходах; звітні конореренції, мовну практику з носіями мови тощо. Процес професійно-мовленнєвої діяльності майбутніх медиків супроводжується мовленнєвими й немовленнєвими обставинами, в яких вони думають і діють у межах профресії відповідно до ситуації та своїх ролей, що сприяє набуттю практичних навичок із фраху, збагаченню життєвого досвіду студентів, розвитку творчого нестандартного мислення та комунікативних навичок і вмінь здійснювати англомовну комунікацію з носіями англійської мови.

Учені (О. Артем'єва, А. Вербицький, Р. Мільруд) вважають, що у низці інновацій вищої школи провідні позиції належать новим засобам, фрормам і методам навчання. У процесі іншомовної підготовки у медичному ЗВО необхідно враховувати основні ознаки методів навчання, які повинні, по-перше, бути певною фрормою руху пізнавальної діяльності студентів (репродуктивної, евристичної, дослідницької); по-друге, бути способом стимулювання та мотивації діяльності; по-третє, слугувати способом обміну інфрормацією між викладачами та студентами; а також розвивати комунікативні вміння і бути певним засобом керування 
пізнавальною діяльністю студентів. Так, Н. Тельтевська зазначає, що саме мета і зміст навчання надають методу ту чи ту спрямованість, характеризують його сутність [5; с. 15]. Отже, характерною рисою кожного методу навчання $€$ його змістова спрямованість, що визначає, які знання, вміння і навички та інтереси необхідно фрормувати.

Ю. Бабанський пропонує алгоритм «оптимального вибору методу навчання», який складається з таких етапів: 1) визначення, чи буде матеріал вивчатися самостійно або під керівництвом педагога; 2) визначення співвідношення репродуктивних і продуктивних методів, перевагу слід надавати продуктивним методам; 3) визначення співвідношення індуктивної і дедуктивної логіки, аналітичного та синтетичного шляхів пізнання. На думку вченого, дедуктивні і синтетичні методи кращі як більш суворі, економні, близькі до наукового викладу; 4) способи поєднання мовленнєвих, наочних, практичних методів; 5) рішення про необхідність застосування методів стимулювання діяльності студентів; 6) визначення методів контролю і самоконтролю; 7) наявність запасних варіантів у разі відхилення реального процесу навчання від запланованого.

Вчений, висуваючи принцип оптимальності під час вибору методів навчання, пропонував виходити 3 того, що певний метод зорієнтований на вирішення певного кола педагогічних і навчальних завдань, однак водночас визнає й опосередковане вирішення інших завдань. Звідси випливає необхідність оцінки можливостей кожного методу навчання, знання його сильних і слабких сторін i, відповідно, вибору їх оптимальних поєднань. Для здійснення оптимального вибору методів, форм і засобів навчання, на думку Н. Тельтевської, слід брати до уваги: 1) відповідність методів, фрорм і засобів навчання особливостям змісту профресійного навчання; 2) індивідуальні, вікові, освітні можливості майбутніх медиків; 3) власні знання різних методів навчання і вміння; 4) час на застосування того чи того методу або комплексу методів [3; с. 79].

Аналіз теоретичних засад і практичне спостереження за освітнім процесом дозволили дійти висновку про необхідність проведення занять, які спонукають до активізації освітньо-мовленнєвої діяльності студентів - майбутніх лікарів і характеризуються такими ознаками: проблемністю, відповідністю освітньо-мовленнєвої діяльності майбутнім професійним завданням і функціям студентів (здійсненням контекстного підходу в навчанні), взаємонавчанням (колективною діяльністю із застосуванням колективної дискусії), індивідуалізацією (урахуванням індивідуальних можливостей студента, а також розвиток у студентів механізмів самоконтролю).

У межах дослідження «розвивальне англомовне середовище» охоплює такі складники: а) англомовне спілкування студентів на ауди- торних заняттях і в позааудиторній діяльності; б) використання різноманітних методів і прийомів, які стимулюють активну англомовну діяльність; в) проведення практичних занять у фрормі дискусій англійською мовою; г) застосування інтерактивних форм навчання.

Зазначені види роботи вимагають занурення студентів у різні методи активної профресійно спрямованої освітньо-мовленнєвої діяльності. 3-поміж них виокремлюємо імітаційні (ігрові та неігрові) методи, що базуються на імітації профресійної діяльності, та неімітаційні. В аспекті дослідження доцільним $€$ залучення студентів до таких імітаційних фрорм: ділових, рольових ігор, імітаційних моделей, ігрових ситуацій. Серед неігрових імітаційних фрорм зазначимо розв'язання й аналіз ситуаційних завдань, вправи, виконання індивідуальних завдань тощо. 3 неімітаційних фрорм було застосовано метод проектів, а також різноманітні інтерактивні форми навчання, як-от: роботу в парах, малих групах, дискусії, інтерв'ю, круглий стіл тощо.

Зміст означеної педагогічної умови передбачає організацію іншомовного середовища професійного спрямування в медичному ЗВО за модельованими комунікативними та рольовими квазіпрофесійними ситуаціями з метою спонукання студентів до профресійно-мовленнєвої англомовної діяльності в межах роботи 3 англомовними текстами й англомовними мовцями (студентами-іноземцями 3 англійською мовою навчання), під час яких студенти демонстрували б отримані знання 3 мовного навчального матеріалу.

Освітні мовленнєві ситуації віддзеркалюють фррагменти об'єктивної дійсності з відповідним офрормленням мовлення комунікантів, тобто в межах мовленнєвої ситуації відбувається апробація зразків і моделей освітньо-мовленнєвої діяльності, фрормується адекватна комунікативна поведінка майбутніх лікарів, активізується їхня увага, фрормується уявлення про реальні норми і стандарти профресійного англомовного спілкування. Найбільш вдалим для впровадження англомовної профресійно спрямованої підготовки є практичне заняття. На практичному занятті $€$ можливість організувати роботу в групі у формі дискусії на профресійно зорієнтовану тему з використанням заздалегідь підготовлених запитань-суджень. Дискусія може проводитися між студентами в неперервній формі, кожен має можливість дійти висновку за розділами вивченої проблеми. Специфріка діалогу у профресійно зорієнтованому навчанні англійської мови як основної фрорми цілеспрямованого обговорення учасників семінару виявляється в тому, що має суб'єкт-суб'єктний характер і проходить найчастіше у фрорматі «студент - студент», подекуди «студент - викладач - студент» у запитально-відповідній фрормі без перекладу з використанням запитань-суджень. 
Такий процес розвиває у студентів - майбутніх лікарів навички мовленнєво-мисленнєвої діяльності, розумові здібності, вміння мислити англійською мовою. Крім цього, англомовна дискусія за профресійно зорієнтованими темами за своїм характером $є$ дослідницькою роботою, і спілкування в цьому разі є навчальним. Уміння оперувати поняттями дозволяє студентам розуміти текст між рядків, тобто, читаючи, уявляти більше, ніж написано, викладати свої думки в логічній послідовності.

Застосування у процесі діалогу дискусії, роботи 3 професійними термінами і поняттями для вирішення професійних завдань, прийомів логічного мислення значно розширює когнітивний і дослідницький характер семінару, розвиває у студентів майбутніх лікарів розумові здібності, вміння мислити англійською мовою, проводити аналітичну роботу, сприяє фрормуванню клінічного мислення.

Навчальне спілкування в контексті фрормування професійно зорієнтованої англомовної підготовки - це активна, практико зорієнтована мовленнєва діяльність у форматі «студент - студент», «студент - група», «група - студент». У дослідженні передбачається використання двох варіантів формування англомовної мовленнєвої діяльності у майбутніх лікарів: а) фрормування навичок англомовної мовленнєвої діяльності за заздалегідь підготовленою темою позааудиторно, зі сфрормульованими запитаннями-судженнями, реалізація яких відбувається на практичному занятті; б) вирішення профресійно зорієнтованого завдання за знайомою темою, що містить повну інорормацію для вирішення цього завдання. За таких умов мовленнєві дії для вирішення проблемного завдання не викликатимуть у студентів значних труднощів. Такий прийом доцільно використовувати на початковому етапі навчання, надалі відпрацювання мовних дій здійснюватиметься за умов, наближених або таких, які імітують професійну діяльність, коли і тема, і професійно зорієнтоване завдання заздалегідь не подаються.

Отже, зважаючи на вищезазначене, доходимо висновку про те, що застосування середовищного підходу має позитивну динаміку і сприяє більш якісному оволодінню майбутніми лікарями англійською мовою профресійного спрямування.

\section{БІБЛІОГРАФІЧНИЙ СПИСОК:}

1. Бурцева Н.М. Межпредметные связи как средство формирования ценностных отношений : дисс. ... канд. пед. наук. Санкт-Петербург, 2001. 231 с.

2. Ожегов С.И., Шведова Н.Ю. Толковый словарь русского языка. Москва : Азбуковник, 1999. 994 с.

3. Тельтевская Н.В. Формирование системы профрессионально-педагогических знаний. Теоретический аспект. Саратов : Изд-во Сарат. ун-та, 2002. 127 c.

4. Тлумачний словник української мови / ред. : Т.В. Ковальова, Л.П. Коврига. Харків : Синтекс, 2002. 672 c.

5. Толковый словарь живого великорусского языка : в 4 т. / сост. В.И. Даль. Москва : Рус. яз. Медиа, 2003. Т. 4. 2003. 688 с.

6. Ясвин В.А. Образовательная среда: от моделирования к проектированию. Москва : Смысл, 2001. 365 c. 